\title{
Proceeding
}

Supplementary Issue: Summer Conferences of Sports Science. Costa Blanca Sports Science Events, 25-26 September 2020. Alicante, Spain.

\section{Preferences of sports tourism consumers}

\author{
LUZ ARELIS MORENO-QUISPE ${ }^{1}$, LUIS ALFREDO ESPINOZA-ESPINOZA², ANTHONY PAUL TAVARA- \\ RAMOS $^{1}$ \\ ${ }^{1}$ Faculty of Hotel Administration and Tourism, National University of Frontera, Peru \\ ${ }^{2}$ Food Industry Engineering School, National University of Frontera, Peru
}

\begin{abstract}
Background: There are few studies about consumer preferences in sports tourism, especially in Peru. The objective of the study was to identify consumer preferences for sports tourism modalities and to analyse the characteristics of students who engage in this activity. It involved 260 student volunteers from a population of 343 students at the Faculty of Hotel Management and Tourism at the National University of Frontera, Sullana, Peru. An open and closed questionnaire was applied to the participants and frequency tests were used for data analysis. The result indicates that $30 \%$ of the students prefer mountaineering, $18.5 \%$ prefer volleyball, and $16.5 \%$ prefer soccer to other sports tourism modalities. $21.5 \%$ and $32.3 \%$ of students preferred to spend one and two days respectively in the sports destination. In addition, $44.6 \%$ of the students identified themselves as sport vacationers and $38.8 \%$ spent less or equal to S/. 100.00 soles when traveling to their tourist destination. The majority of participants used the internet and social networks to plan and share their travel experience. Conclusions: Students of tourism prefer mountaineering and do not identify themselves as passive or active sports tourists, but rather as sports vacationers.

Keywords: University students; Sport activity; Mountaineering; Social networks; Consumer behaviour.

\section{Cite this article as:}

Moreno-Quispe, L.A., Espinoza-Espinoza, L.A., \& Tavara-Ramos, A.P. (2020). Preferences of sports tourism consumers. Journal of Human Sport and Exercise, 15(4proc), S1469-S1475. doi:https://doi.org/10.14198/jhse.2020.15.Proc4.43

Corresponding author. Faculty of Hotel Administration and Tourism, National University of Frontera, Peru. https://orcid.org/0000-0003-1332-5739

E-mail: Imoreno@unf.edu.pe

Abstract submitted to: Spring Conferences of Sports Science. Costa Blanca Sports Science Events, 19-20 June 2020. Alicante, Spain.

JOURNAL OF HUMAN SPORT \& EXERCISE ISSN 1988-5202

(c) Faculty of Education. University of Alicante

doi:10.14198/jhse.2020.15.Proc4.43
\end{abstract}




\section{INTRODUCTION}

Sports tourism is the trip that the tourist makes with the motivation of moving away from his habitual residence to carry out a sport activity, participate in a sport event, or visit a museum or a sports stadium. Active sport tourism is characterized by the motivation of the tourist to carry out the sport activity and passive sport tourism is when the tourist is a spectator of the sport (Paniza-Prados et al., 2019). However, the sports vacationer refers to the tourist who develops sports activities or is a circumstantial spectator of a sports event when he travels to a tourist destination for vacation (Latiesa \& Paniza, 2006).

In this sense, sports and recreational tourism are becoming more relevant, mainly in coastal areas with a higher seasonality. However, certain difficulties have become evident due to weak organization and a greater concentration of people in small towns (Hegeduš et al., 2017). In these locations, sports activities positively impact the environment in several ways. Sports activities impact urban development with better infrastructure, consolidate the community, promote socio-cultural exchange, improve the visibility and image of the community and offer knowledge and entertainment to the population and tourists; but sports activities also generate some negative impacts. Some negative impacts include economic costs, traffic on the roads, security, environmental concern and social conflicts (Njoroge et al., 2017).

In this regard, the sport that promotes a country and communicates a positive image increases the territory's popularity as a tourist destination. In this process, the role of the media in consumer preferences has been key (Mataruna-Dos-Santos, 2020). In addition, the creation of an umbrella brand that integrates the diversity of sports activities, workshops and interviews with sports organizers allows the introduction of nature as an important pillar in the preferences of sports tourists (Perić et al., 2017).

A recent study has shown that leisure and happiness are motivations for motorcyclists because they seek a healthy lifestyle, suggesting the segmentation of sports activities to attract tourists who attend shows or perform outdoor activities related to nature (Kruger \& Venter, 2020).

From another perspective, sports events can become a mechanism for the development of tourist destinations through the consumption of products and services that use the resources and skills of several companies in a territory (Mackellar \& Nisbet, 2017). One such case is the Tour de France which attracts nearly 11 million tourists along the roadside. This is a great example of an opportunity for local development dedicated to hospitality; it generates direct and indirect financial benefits (Varnajot, 2020).

For their part, schools have integrated sport and psychology into educational training, motivating the work of the trainer (Mikhaylova, 2018). In this regard, a study focused on children from 5 to 7 years old showed that those who perform exercises with medium and high intensity showed favorable physiological, psychological and behavioral changes (Krivolapchuk et al., 2020). In secondary education, the impact of sports practice on physical development, adaptation skills, physical fitness, and functional status has also been evaluated. It was observed that the functional capacity of the body is associated with the development of skills, strength and coordination, creating a healthier lifestyle for people (Parfenova et al., 2020).

The practice of sports and the development of communication skills have been positively correlated in young university students (Karakullukçu, 2020). In addition, it has been reported that the best grades earned by college students correlated with their involvement in sports practice. It showed that sports practice was positively correlated with improving critical thinking and interpersonal skills among students (Lukianets \& Lukianets, 2020). 
In this regard, it is not clear if university students prefer some form of sports tourism. Therefore, the objective of the study was to identify the consumer preferences of the modalities of sport tourism and to analyse the characteristics of the students who carry out this activity.

\section{METHODS}

This is a descriptive study conducted at the National University of Frontera, Peru. The duration of the study was from September 2019 to August 2020. A questionnaire was applied with open and closed questions about the consumption preferences of sport tourism. The participants were 260 student volunteers from a population of 343 people from the School of Hotel Management and Tourism. All the students resided in the Piura region and the informed consent of the participants and the Declaration of Helsinki, as well as its subsequent revisions, were assessed throughout the research process. Frequency tests were carried out to analyse the variables and SPSS v20 software was used.

\section{RESULTS}

Participants were $70 \%$ female and $30 \%$ male out of a total of $260 / 100 \%$ students. Most were between 18 and 25 years old and $93.8 \%$ were single. In addition, $41.5 \%$ had no monthly income and $40.4 \%$ had an income below or at the limit of the minimum wage, which in Peru amounts to S/. 930.00 a month; only $18.1 \%$ had an income above the minimum wage. this is presented in Table 1.

Table 1. Characteristics of the students.

\begin{tabular}{lcc}
\hline Gender & Frequency & $\%$ \\
\hline Man & 78 & 30.0 \\
Woman & 182 & 70.0 \\
Total & 260 & 100 \\
\hline Marital status & & \\
\hline Married & 3 & 1.2 \\
Co-habitant & 13 & 5.0 \\
Single & 244 & 93.8 \\
Total & 260 & 100 \\
\hline Monthly income & & \\
\hline Greater than or equal to S/.930.00 & 47 & 18.1 \\
Less than SI. 930.00 & 105 & 40.4 \\
No income & 108 & 41.5 \\
\hline Total & $\mathbf{2 6 0}$ & 100 \\
\hline
\end{tabular}

Regarding the sports tourism modalities, of the total number of students, $30 \%$ prefer mountaineering, $18.5 \%$ prefer volleyball and $16.5 \%$ prefer soccer to other sports tourism modalities. This is presented in Table 2.

$29.2 \%$ of the students indicated that they normally used the internet to plan their vacation or sports activities and $35.8 \%$ reported that they always used the internet. $75 \%$ of the students indicated that they preferred to receive information about their tourist destination or sport activity through social networks and $15.8 \%$ preferred web pages as a means of information about their sport destination. In addition, $21.5 \%$ and $32.3 \%$ of students preferred to spend one and two days respectively when doing sports tourism as opposed to other days. 
Table 2. Modalities of sports tourism referred by students.

\begin{tabular}{lcc}
\hline Types of sports tourism & Frequency & $\%$ \\
\hline None & 2 & 0.8 \\
Adventure / sun and beach & 1 & 0.4 \\
Athletics & 2 & 0.8 \\
Basketball & 10 & 3.8 \\
Surfing & 10 & 3.8 \\
Cycling & 31 & 11.9 \\
Swimming & 35 & 13.5 \\
Soccer & 43 & 16.5 \\
Volleyball & 48 & 18.5 \\
Mountaineering & 78 & 30.0 \\
\hline Total & $\mathbf{2 6 0}$ & $\mathbf{1 0 0}$ \\
\hline
\end{tabular}

Of the total number of students, $29.2 \%$ of women and $15.4 \%$ of men, respectively, identified themselves as sport tourists and $28.8 \%$ of women and $6.5 \%$ of men did not identify themselves as sport tourists, compared to other active or passive tourists. This result is presented in Table 3.

Table 3. Identification of students as sport or vacation tourists.

Type of sport tourist

I don't identify myself as a sports tourist
Man Woman Total

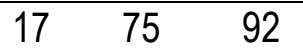

\begin{tabular}{lll}
$6.5 \%$ & $28.8 \%$ & $35.4 \%$ \\
\hline
\end{tabular}

I am an active sports tourist: Because I practice sports freely or attend organized $12 \quad 22 \quad 34$ competitions

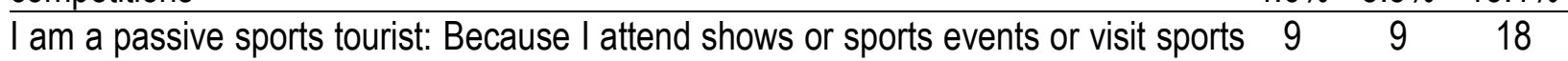
museums or sports stadiums I am a sports vacationer: Because I move away from my usual residence for vacations $40 \quad \begin{array}{llll}40 & 116\end{array}$ and I take advantage to do a sport activity Total $15.4 \% 29.2 \% \quad 44.6 \%$ $\begin{array}{lll}78 & 182 & 260\end{array}$ $30.0 \% 70.0 \% 100.0 \%$

With regard to student spending when they do sports tourism, $38.8 \%$ spend less or equal to S/. 100.00 , $29.2 \%$ spend more than S/. 100.00 and up to S/. 300.00 compared to other students who do not do sports tourism. This result is presented in Table 4.

Table 4. Student spending when doing sports tourism.

\begin{tabular}{lcc}
\hline I spend & Frequency & $\%$ \\
\hline More than 600 soles & 5 & 1.9 \\
More than 100 soles to 300 soles & 76 & 29.2 \\
More than 300 soles to 600 soles & 28 & 10.8 \\
Less or equal to 100 Soles & 101 & 38.8 \\
Inever do sport tourism & 50 & 19.2 \\
\hline Total & $\mathbf{2 6 0}$ & $\mathbf{1 0 0}$ \\
\hline
\end{tabular}




\section{DISCUSSION}

There is little evidence to identify the quality of tourist service from the perspective of the sports consumer. According to (Szczechowicz, 2012); students prefer tourist packages that include sport activities except risky sports.

In our study we observed that mostly tourism students identified themselves as sport vacationers and the sport they preferred was mountaineering. According to (Eganov et al., 2020), female students prefer sports such as; gymnastics, hiking, athletics, aerobics, shaping, step aerobics, dance, skiing, judo, sambo and karate. These students are those who have better communication skills, better adaptation to certain stimuli and diverse social conditions, and are in better moods. In addition, sports give them the ability to control emotions and create their own opinion, increasing the desire to study and participate in work.

In this regard, sport tourism is one of the most accessible ways for students to develop their personality, selfdetermination, self-confidence and personal fulfilment by communicating and socializing with their peers and other social groups when they engage in sport (Neretina et al., 2016).

Our findings show that the majority of students are young people who prefer to receive information about their sports destination through social networks and websites, in addition; most young people used the internet to plan their vacations. This information coincides with (Jazdzewska \& Jagnuszewska, 2017), who reported that the internet was indispensable for young people to organize a trip and share their vacation experience.

Another important aspect is the use of computer applications and technology to promote the tourist destinations of a country to the segment of young students, who are often mobilized at the stage of university education (Fadzil, N. A. S. N. M. et al., 2020). In this regard, it is important that tourism schools, associations and networks disseminate through their websites the trends in sports tourism to facilitate tourists in organizing their travel and sports activities and, on the other hand, allow companies to improve the supply of sports services (Hegazy, 2020).

Our study has limitations because it only focused on college students, who reside in one region and most of the participants were young people, especially women, between 18-25 years old. We did not collect information about the physical exercises that the participants did during their sports training and the dates that they usually do sports tourism. We also did not collect information from the participants about the sport activity in relation to their personality, self-determination and health situation.

In the region of Piura, there is little investment in sports infrastructure. The annual budget for the Institutional Operational Plan in the area of tourism is approximately S/.140,000.00 and this is a weakness that should be strengthened in order to promote tourism in Piura. In this regard, according to (Doroz-Turek, 2019), investment in sports infrastructure for students is often appropriate. However, in rural areas there is less investment in projects focused on students, which allows for a more dynamic environment, but with a poor infrastructure.

Passive tourism is considered to be the most popular, and may be due to lack of sports equipment, parental consent, and students' sports skills (Mei \& Lantai, 2018). In our study we did not collect this information, but it is important to consider in future research related to sport tourism. 
Sport is a holistic discipline that contributes to university education and health (Dopsaj et al., 2020) points out that sports complement the body balance of young people between 20 and 24 years of age, because he observed $6.85 \%$ of cases with low weight and $3.13 \%$ with obesity. In addition, a recent publication reported that people who practice sports and even under conditions of stress show a haematological and neuroimmune reserve (Pavlova et al., 2020). In that sense, the practice of sports is related to the well-being of the human being and generates more health benefits to tourists.

\section{CONCLUSIONS}

University tourism students identify themselves as vacation sports tourists; most prefer mountaineering, volleyball and soccer to other forms of sports tourism. The use of the internet and social networks are indispensable for a young person to plan their trip. Future studies related to sports vacationers and the tourism infrastructure offered by the region are necessary.

\section{ACKNOWLEDGEMENT}

We are grateful to Elizabeth Christensen for her support in reviewing the manuscript in English.

\section{REFERENCES}

Dopsaj, M., Djordjević-Nikić, M., Khafizova, A., Eminović, F., Marković, S., Yanchik, E., \& Dopsaj, V. (2020). Structural body composition profile and obesity prevalence at female students of the university of Belgrade measured by multichannel bioimpedance protocol. Human Sport Medicine, 20(2), 53-62. https://doi.org/10.14529/hsm200207

Doroz-Turek, M. (2019). Revitalization of small towns and the adaptive reuse of its cultural heritage. Ms\&e, 471(5), 052006. https://doi:10.1088/1757-899X/471/5/052006

Eganov, A., Cherepov, E., Romanova, L., \& Bykov, V. (2020). Interpersonal communication of students and mental health data. Journal of Physical Education and Sport, 20, 2405-2408.

Fadzil, N. A. S. N. M., Lah, H. A., \& Mustafa, W. A. (2020). (2020). The usage of virtual reality technology through histopology application to increase orang asli imagination skill in history. Paper presented at the Journal of Physics: Conference Series, 1529(4). https://doi.org/10.1088/1742$6596 / 1529 / 4 / 042065$

Hegazy, O. (2020). Online sports activities travel guide (SATG). https://doi.org/10.1007/978-3-03039445-5_16

Hegeduš, I., Gregoric, M., Skryl, T. V., Romanyuk, A. V., \& Gureeva, E. A. (2017). Sports and recreational tourism of koprivnica krizevci county in republic of Croatia. Journal of Environmental Management and Tourism, 8(8), 1595-1603.

Jazdzewska, I., \& Jagnuszewska, A. (2017). Tourism-themed internet portals - are new media creating a new tourist? A case study of polish students. Bulletin of Geography, 35(35), 35-44. https://doi.org/10.1515/bog-2017-0003

Karakullukçu, Ö F. (2020). The effect of communication competence on alienation in sports: A research on university students. Acta Medica Mediterránea, 36(2), 1089-1094. https://doi.org/10.19193/0393$6384 \_2020 \_2 \quad 171$

Krivolapchuk, I. A., Chernova, M. B., \& Gerasimova, A. A. (2020). Effect of regular physical activity of various intensity on the functional status of 5-6 and 6-7-year-old children. Human Sport Medicine, 20(2), 71-79. https://doi.org/10.14529/hsm200209 
Kruger, S., \& Venter, D. (2020). I can't buy happiness but could own a motorcycle: Does leisure life matter? African Journal of Hospitality, Tourism and Leisure, 9(4), 469-483.

Latiesa, M., \& Paniza, J. L. (2006). Turistas deportivos. una perspectiva de análisis. Revista Internacional de Sociología, 64(44), 133-149.

Lukianets, H., \& Lukianets, T. (2020). Global communication competence: A framework of intercultural skills development in sport and tourism higher education. Teoria Ta Metodika Fizicnogo Vihovanna, 20(2), 77-85. https://doi.org/10.17309/tmfv.2020.2.03

Mackellar, J., \& Nisbet, S. (2017). Sport events and integrated destination development. Current Issues in Tourism, 20(13), 1320-1335. https://doi.org/10.1080/13683500.2014.959903

Mataruna-Dos-Santos, L. J. (2020). The intentions of international tourists to attend the 2016 Rio Summer Olympic and Paralympic Games: A study of the image of Rio de Janeiro and Brazil. Annals of Applied Sport Science, 8(3). https://doi.org/10.29252/aassjournal.798

Mei, X. Y., \& Lantai, T. (2018). Understanding travel constraints: An exploratory study of Mainland Chinese international students (MCIS) in Norway. Tourism Management Perspectives, 28, 1-9. https://doi.org/10.1016/j.tmp.2018.07.003

Mikhaylova, T. V. (2018). Nearing 100th anniversary of Gtsolifk, leading Russian sport university. Teoriya i Praktika Fizicheskoy Kultury, (5), 3-4.

Neretina, T. G., Orekhova, T. F., Ovsyannikova, E. A., \& Klevesenkova, S. V. (2016). Students' health and recreation tourism promotion experience. Teoriya i Praktika Fizicheskoy Kultury, 2016-January (8), 41-43.

Njoroge, J. M., Atieno, L., \& Do Nascimento, D. V. (2017). Sports tourism and perceived socio-economic impact in kenya: The case of Machakos county. Tourism and Hospitality Management, 23(2), 195 217. https://doi.org/10.20867/thm.23.2.9

Paniza-Prados, J. L., Puertas-Cañaveral, I., \& Jiménez-Cabello, J. M. (2019). La investigación en el turismo deportivo: Conceptualización, operacionalización y análisis. Sociología del Turismo, 45, 127.

Parfenova, L. A., Glazkova, G. B., \& Gerasimov, E. A. (2020). Evaluation of a sports-specific approach in physical education of secondary school students with health-related issues. Human Sport Medicine, 20(2), 132-138. https://doi.org/10.14529/hsm200216

Pavlova, V. I., Mamylina, N. V., Semchenko, A. A., Kamskova, Y. G., \& Saraykin, D. A. (2020). The peripheral component of erythron and cytokine profile in students in response to examination stress. Human Sport Medicine, 20(1), 36-42. https://doi.org/10.14529/hsm200105

Perić, M., Čuić Tanković, A., \& Đurkin, J. (2017). Role of brand personality traits in creating an umbrella brand for small-scale sports events: The Case of Gorski Kotar, Croatia. Drustvena Istrazivanja, 26(4), 561-581. https://doi.org/10.5559/di.26.4.06

Szczechowicz, B. (2012). The importance of attributes related to physical activity for the tourism product's utility. Journal of Sport and Tourism, 17(3), 225-249. https://doi.org/10.1080/14775085.2012.734061

Varnajot, A. (2020). The making of the tour de France cycling race as a tourist attraction. World Leisure Journal, 62(3), 272-290. https://doi.org/10.1080/16078055.2020.1798054

\section{(9) $\odot \Theta \Theta$}

This work is licensed under a Attribution-NonCommercial-NoDerivatives 4.0 International (CC BY-NC-ND 4.0). 